\title{
Effects of a Weight Management Program on Body Composition, and Calcium, Zinc, and Iron Intake in Middle-aged Women with Obesity
}

\author{
Jung-Soon $\mathrm{Han}^{1}$, Yookyung $\mathrm{Kim}^{2 *}$ \\ ${ }^{1}$ Research Institute of Human Ecology, College of Education, Korea University, Seoul, Korea \\ ${ }^{2}$ Department of Home Economics Education, College of Education, Korea University, Seoul, Korea
}

\begin{abstract}
"Corresponding author: Yookyung Kim, Department of Home Economics Education, College of Education, Korea University, 145 Anam-ro, Seongbuk-gu, Seoul 02841, Korea
\end{abstract}

Tel.: +82232902328

Email: yookyung_kim@korea.ac.kr

Received September 16, 2018

Revised January 14, 2019

Accepted January 17, 2019

Published March 30, 2019

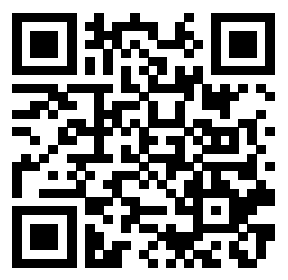

\begin{abstract}
Purpose: We sought to observe the effects of a body weight management program on body composition, physical activity, and intake of calcium, zinc, iron, and other nutrients in middle-aged women with obesity. Methods: Middle-aged women with obesity were divided into the following 2 groups: weight management plus nutrition education and exercise (WM-NE) and weight management and exercise (WM-E). Then, we observed their anthropometric parameters, physical activity and dietary intake for 3 months. Results: Both groups showed a significant decrease in the mean body weight, BMI, body fat, body fat mass, waist circumference, and waist/hip ratio and showed a significant increase in endurance and flexibility after participating in the weight management program. The intake of calcium, zinc and iron in both groups decreased after participation in the weight management program. Conclusion: Consequently, the weight management program decreased body fat and waist circumference and increased physical fitness. These are positive steps for obesity improvement in middle-aged women with obesity. However, intake of calcium, zinc, and iron decreased; especially, calcium intake was insufficient. Therefore, we would like to study the weight management programs to improve bone health in middle-aged women with obesity.
\end{abstract}

Keywords: Weight management program, Calcium, Zinc, Iron, Middle-aged women with obesity

\section{Introduction}

비만은 에너지 섭취와 소비의 불균형, 신체 활동량의 부족, 대 사이상 및 부적절한 습관과 같은 여러 환경적, 유전적, 내분비적 요인이 복합적으로 연관되어 체지방이 과도하게 축적된 것으로 (Friedman, 2009), 당뇨병, 고혈압, 이상지질혈증 같은 대사질 환의 주요 원인으로 삶의 질을 저하시키고 사망률을 증가시킨다 (Matthews et al., 2010). 여성은 중년 이후에 과체중과 비만이 급증하는데 이는 기초대사량의 저하, 신체활동량의 감소, 여성호 르몬인 에스트로겐(estrogen)이 감소되면서 체지방이 복부로 이 동해 내장에 축적되는 중심성 지방분포가 급격하게 나타나고, 제 지방량(근육량)의 감소, 지방분해 활동 저하로 인하여 체지방이 증가하기 때문이다(Karvonen-Gutierrez \& Kim, 2016). 아시
아 여성의 경우, 같은 체질량 지수를 가진 백인 여성에 비해 복부 내장지방이 상대적으로 많다는 선행연구가 보고되어(Lim et al., 2011) 있으며, 동물성 식품, 포화 지방, 나트륨이 많이 함유된 가 공식품 섭취 증가와 식사의 불규칙성 등의 식습관 패턴 등이 복합 적으로 작용하여 복부비만을 더욱 심화시킨다(Lee \& Lee, 2010, $\operatorname{Kim} \& \operatorname{Sim}, 2018)$. 칼슘은 신체에서 가장 풍부한 무기질로 대 부분의 체내 칼슘은 골격과 체조직을 구성하고, 혈액이나 근육에 존재하여 혈액응고 및 신경전달 등 다양한 생리기능을 조절한다 (Peacock, 2010). 그러나 2015년 질병관리본부에서 실시한 국민 건강영양조사에 따르면 우리나라 국민 칼슘 섭취 현황은 섭취 기 준 대비 평균 섭취량이 남녀 모두 부족한 수준이며, 1-2세를 제 외한 전 연령층에서 취약한 섭취 수준으로 한국인에게 가장 부 족하기 쉬운 영양소 중의 하나이다(Korea Centers for Disease 
Control and Prevention, 2017). 만성대사질환 유병 위험도가 상 대적으로 높고 노화로 인해 근감소증과 각종 골격질환이 우려되는 중노년기의 경우 다른 연령층에 비해 칼슘 섭취량이 상대적으로 부 족한 수준으로(Hur et al., 2018), 중년기 이후의 빠른 골소실을 유도한다(Zhu et al., 2005). 특히 중년여성의 경우 호르몬 변화와 연령이 증가함에 따라 체지방이 증가하고 노화가 진행됨에 따라 근 감소가 진행되어 골 강도의 약화와 골절의 위험이 증가하는 근감소 성-골다공증 비만(Ilich et al., 2014)에 대한 관심이 증대되는 시 점에 충분한 칼슘 섭취는 매우 중요하다(Rachner, 2011). 또한 비 만은 면역기능을 저하시켜 감염의 위험을 증가시킨다(Locniskar et al., 1983). 특히 최근에는 건강에 대한 관심 증대와 함께 면역 기능에 영향을 미치는 무기질에 대한 관심이 있으며 아연이 주목 받고 있으나 이에 관련된 연구는 아직 많지 않다. 동물실험에서 유 전적 비만쥐는 정상쥐에 비해 털과 혈청, 간의 아연 함량이 낮았으 며(Lin et al., 1992), 사람에서도 머리카락과 혈청의 아연 함량은 체중이 증가할 수록 감소하였다고 한다(Chen et al., 1988). 비만 한 사람들은 열량과잉과 미량 영양소인 철이나 구리 등의 섭취 부 족으로 인한 영양 불균형 상태가 나타나 무기질 대사 장애가 올 수 있다는 보고(Luque-Díaz et al., 1982)로 미루어 비만으로 인한 면역능력의 저하는 심각할 수 있으므로 비만과 미량 무기질에 대한 연구가 필요한 시점이다. 그러나 과체중이나 비만에 대한 칼슘과 아연 섭취관련 연구는 없는 실정이다. 이에 본 연구에서는 과체중 및 비만한 중년여성에게 체중관리프로그램을 실시하였을 때 체성 분과 칼슘과 아연, 철 섭취 변화에 미치는 영향을 관찰하여 비만인 및 건강인 대상 영양교육 프로그램 개발과 식단작성에 유용한 자료 로 활용하고자 한다.

\section{Methods}

1. 연구대상 및 기간
대상자들은 경기도에 거주하며 질병치료 및 약물복용을 하 지 않는 체질량지수(body mass index, BMI) 25 이상인 중년 의 여성 44 명 즉 영양과 운동교육군(weight managementnutrition and exercise, WM-NE) 22명, 운동교육군(weight management-exercise, WM-E) 22명으로 2016년 4월부터 6 월까지 12 주간 체중관리프로그램을 받았다.

\section{2. 신체계측}

대상자의 신장 $(\mathrm{cm})$ 과 체중 $(\mathrm{kg})$ 은 자동측정기 $(\mathrm{DS}-102$; Jenix, Korea)를 이용하여 측정하였으며 체질량지수는 체중 $(\mathrm{kg}) /$ 신장 $\left(\mathrm{m}^{2}\right)$ 의 공식을 이용해 산출하였다. 허리둘레는 숨을 편안히 내쉬는 직립자세에서 최하위 늑골하부와 골반 장골릉과 의 중간부위를, 엉덩이둘레는 가장 돌출된 부위를 측정하여 허 리 엉덩이 둘레 비율(waist hip ratio, WHR)을 산출하였다. 신 체구성은 제지방은 body composition analyzer (X-scan 970; JAWON medical Co., Korea)를 이용하여 지방량(fat mass, $\mathrm{kg})$, 제지방량(lean body mass, $\mathrm{kg})$, 체지방률(\% body fat, \%) 을 측정하였다.

\section{3. 식사섭취조사}

대상자들은 영양과 운동교육군(WM-NE), 운동교육군(WM$\mathrm{E})$ 으로 나누어 영양과 운동교육, 운동교육으로 이루어진 체중관 리를 받았다. 영양과 운동교육을 받은 군과 운동만 수행한 군 모 두 식사섭취 조사는 매일 아침 기상부터 취침할 때까지 1일 동안 아침, 점심, 저녁식사와 간식과 물을 포함하여 섭취한 모든 음식 의 종류와 그에 따른 각각의 식품재료의 종류와 분량을 조사하였 다. 식사에 대한 조사를 표준화하기 위해 모형과 사진을 제시하 여 조사대상자가 섭취한 음식의 양을 정확하게 기억할 수 있도록 하였으며 식사기록지를 제공하여 식사 후 바로 기록하도록 하였 다. 교육 전과 교육 후 수거된 식사기록지는 CAN-Pro (version 3.0; The Korean Nutrition Society, Korea)을 이용하여 영양

Table 1. Nutrition education contents of the weight management program

\begin{tabular}{cl}
\hline Week & \multicolumn{1}{c}{ Contents } \\
\cline { 2 - 2 } 1 & Explain about recording within a food diary \\
2 & Obesity-related diseases and hazards \\
3 & Explanation of nutrients, including carbohydrates and proteins \\
4 & Explanation of nutrients, including lipids and vitamins \\
5 & Explanation of nutrients, including minerals and water \\
6 & Explanation of nutrients, including dietary fiber and health \\
7 & Explanation of dietary reference intakes for Koreans \\
8 & Explanation of the food composition bicycle and food exchange table \\
9 & Menu planning \\
10 & Explanation of the importance of weight control and health \\
11 & Importance of weight maintenance \\
12 & Life style modification \\
\hline
\end{tabular}


소 섭취상태를 파악하였다.

\section{4. 체중관리프로그램}

체중관리프로그램은 영양과 운동교육으로 이루어져 있으며 체중관리에 대한 개요, 식사일지, 정상체중, 비만에 대한 올바른 이해, 원인, 종류, 비만으로 유발되는 질환, 영양소(탄수화물, 단백질, 지방, 비타민, 무기질, 수분, 섬유소), 영양소 섭취기 준, 식품구성자전거, 식품교환, 식사계획 및 조절, 건강한 체중 의 중요성, 잘못된 식습관 고치기(간식의 열량비교, 잘못된 식습 관의 교정), 외식 시 식품선택요령(열량, 탄수화물, 지방 등이 많 은 음식 선택보다 단백질, 비타민, 무기질이 함유된 식품 소개), 조리방법, 생활습관과 행동수정 등에 관한 내용으로 구성되었다 (Table 1). 운동은 중강도 걷기 운동을 기상 후 안정 시 심박수 를 측정하여 예비심박수(heart rate reserve, HRR) 60\%[0.6× (최대심박수-안정 시 심박수)+안정 시 심박수]의 운동강도를 설 정하여 목표 심박수를 제시하고 트레드밀(treadmill)에서 주 5 회 1 일 $60 \mathrm{~min}$ 실시하고 근력운동은 1 repetition mum (RM) $70 \%$ 강도로 10 회씩 3 set 운동하였다. 이와 병행하여 운동의 이점, 비만관리를 위한 운동의 실제, 열량소비를 위한 운동 종류 등에 대한 내용을 교육하여 지속적으로 흥미를 유발하면서 운동 을 할 수 있도록 구성하여 실시하였다. 운동만 수행한 군은 영양
교육을 제외한 모든 프로그램을 동일하게 수행하였다.

\section{5. 체력측정}

대상자들의 체력을 평가하기 위해 교육 전·후에 근지구력, 유 연성, 근력을 측정하였다(Cho \& Son, 1998).

\section{6. 자료 분석}

조사한 모든 자료의 통계분석은 SPSS package (version 18.0 ; IBM, USA)을 이용하여 $p<0.05$ 수준에서 유의성을 검증 하였다.

\section{Results and Discussion}

\section{1. 연구대상자의 일반적 특성}

연구대상자들의 일반적인 특성은 Table 2 와 같다. WM-NE 군의 평균연령은 46.2 세이고 키는 $157.06 \mathrm{~cm}$, 체중은 76.46 $\mathrm{kg}$ 이며, 체질량지수(BMI)는 $30.89 \mathrm{~kg} / \mathrm{m}^{2}$, 허리둘레는 94.99 $\mathrm{cm}$ 이었다. $\mathrm{WM}-\mathrm{E}$ 군의 평균연령은 46.5 세이고 신장은 159.01 $\mathrm{cm}$, 체중은 $73.6 \mathrm{~kg}$ 이며, 체질량지수는 $29.07 \mathrm{~kg} / \mathrm{m}^{2}$, 허리둘 레는 $93.55 \mathrm{~cm}$ 이었다.

Table 2. Characteristics of subjects

\begin{tabular}{lcc}
\hline Variables & WM-NE group & WM-E group \\
Age $(\mathrm{yrs})$ & $46.20 \pm 6.20$ & $46.50 \pm 7.10$ \\
Height $(\mathrm{cm})$ & $157.06 \pm 5.20$ & $159.01 \pm 5.32$ \\
Body weight $(\mathrm{kg})$ & $76.46 \pm 11.15$ & $73.60 \pm 7.46$ \\
BMI $\left(\mathrm{kg} / \mathrm{m}^{2}\right)$ & $30.89 \pm 3.25$ & $29.07 \pm 2.16$ \\
Waist circumference $(\mathrm{cm})$ & $94.99 \pm 8.03$ & $93.55 \pm 6.44$ \\
\hline
\end{tabular}

WM-NE, weight management program-nutrition education and exercise; WM-E, weight management program-exercise; BMI, body mass index. Data are represented as mean \pm standard deviation.

Table 3. Body composition comparison of the WM-NE and WM-E groups, consisting of middle-aged with obesity

\begin{tabular}{|c|c|c|c|c|c|}
\hline & & Before & After & $t$ & $p$ \\
\hline \multirow{2}{*}{ Body weight (kg) } & WM-NE & $76.46 \pm 11.15$ & $68.45 \pm 9.22$ & 8.184 & 0.001 \\
\hline & WM-E & $73.60 \pm 7.46$ & $70.93 \pm 8.22$ & 5.823 & 0.001 \\
\hline \multirow{2}{*}{$\mathrm{BMI}\left(\mathrm{kg} / \mathrm{m}^{2}\right)$} & WM-NE & $30.89 \pm 3.25$ & $27.68 \pm 2.79$ & 7.535 & 0.001 \\
\hline & WM-E & $29.07 \pm 2.16$ & $27.99 \pm 2.37$ & 5.932 & 0.001 \\
\hline \multirow{2}{*}{ Body fat (\%) } & WM-NE & $38.32 \pm 1.96$ & $34.63 \pm 2.84$ & 6.251 & 0.001 \\
\hline & WM-E & $36.44 \pm 2.08$ & $32.63 \pm 4.82$ & 4.056 & 0.004 \\
\hline \multirow{2}{*}{ Body fat mass (kg) } & WM-NE & $29.35 \pm 5.20$ & $24.61 \pm 5.56$ & 6.459 & 0.001 \\
\hline & WM-E & $28.44 \pm 4.64$ & $24.09 \pm 4.70$ & 3.901 & 0.001 \\
\hline \multirow{2}{*}{ Waist circumference $(\mathrm{cm})$} & WM-NE & $94.99 \pm 8.03$ & $86.67 \pm 6.60$ & 7.975 & 0.001 \\
\hline & WM-E & $92.55 \pm 6.44$ & $86.92 \pm 6.21$ & 6.104 & 0.001 \\
\hline \multirow{2}{*}{ Waist/hip ratio } & WM-NE & $0.90 \pm 0.03$ & $0.86 \pm 0.03$ & 6.125 & 0.001 \\
\hline & WM-E & $0.88 \pm 0.03$ & $0.84 \pm 0.02$ & 5.703 & 0.001 \\
\hline \multirow{2}{*}{ Lean body mass (kg) } & WM-NE & $42.85 \pm 5.57$ & $41.52 \pm 5.30$ & 7.935 & 0.001 \\
\hline & WM-E & $43.41 \pm 3.14$ & $42.87 \pm 4.88$ & 6.013 & 0.004 \\
\hline
\end{tabular}

WM-NE, weight management program-nutrition education and exercise; WM-E, weight management program-exercise; BMI, body mass index. Data are represented as mean \pm standard deviation $(p<0.05)$. 


\section{2. 체성분, 체지방 성상 변화}

$\mathrm{WM}-\mathrm{NE}$ 군과 $\mathrm{WM}-\mathrm{E}$ 군의 체중관리프로그램 참여 전·후 체성분에 대한 결과는 Table 3 에 제시한 바와 같다. $\mathrm{WM}-\mathrm{E}$ 군 은 체중은 $76.46 \pm 11.15 \mathrm{~kg}$ 에서 $68.45 \pm 9.22 \mathrm{~kg}$ 으로 감소하 였으며, BMI는 $30.89 \pm 3.25$ 에서 27.68 2.79 로, 허리둘레는 $94.99 \pm 8.03 \mathrm{~cm}$ 에서 $86.67 \pm 7.6 \mathrm{~cm}$ 로, 복부비만율은 0.90 \pm 0.03 에서 $0.86 \pm 0.03$ 으로, 체지방율은 $38.32 \pm 1.96 \%$ 에서 $34.63 \pm 2.84 \%$ 로, 체지방량은 $29.35 \mathrm{~kg}$ 에서 $24.61 \mathrm{~kg}$ 으로 모 두 유의하게 감소하였다. $\mathrm{WM}-\mathrm{E}$ 군은 체중 $73.60 \pm 7.46 \mathrm{~kg}$

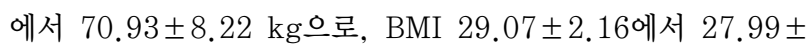
2.37, 허리둘레 $92.55 \pm 6.44 \mathrm{~cm}$ 에서 $86.92 \pm 6.21 \mathrm{~cm}$ 로, 체지 방율 $36.44 \pm 2.08 \%$ 에서 $32.63 \pm 4.82 \%$ 로 복부비만율 $0.88 \pm$ 0.03 에서 $0.84 \pm 0.03$ 로, 체지방량 $28.44 \pm 4.64 \mathrm{~kg}$ 에서 24.09 $\pm 4.70 \mathrm{~kg}$ 으로 유의하게 감소하였다. 그러나 제지방조직(lean body mass)은 WM-NE군은 $42.85 \pm 5.57 \mathrm{~kg}$ 에서 $41.52 \pm$ $5.30 \mathrm{~kg}$ 으로, $\mathrm{WM}-\mathrm{E}$ 군은 $43.41 \pm 3.14 \mathrm{~kg}$ 에서 $42.87 \pm 4.88$ $\mathrm{kg}$ 으로 두 군 모두 감소하였다. 이는 체중이 감소하면서 체지 방도 감소하고 이와 함께 제지방량도 감소한 것으로 보인다. 이 는 비만여성에게 12 주간 걷기 운동을 수행시켰을 때 $43.67 \mathrm{~kg}$ 에서 $42.98 \mathrm{~kg}$ 으로 감소한 연구와는 비슷한 결과가 나왔으나 (Kim, 2017), 다른 연구에서 비만여성에게 10주 간의 유산소 운 동은 제지방량을 $43.75 \mathrm{~kg}$ 에서 $45.58 \mathrm{~kg}$ 으로 증가시켰다는 결 과(Kim \& Kim, 2017)와는 다른 경향을 나타내었다. WM-NE 군과 $\mathrm{WM}-\mathrm{E}$ 군 모두 체지방, 체지방율, 허리둘레, 복부비만율, 체지방량을 감소시켜 영양교육과 운동이나 운동은 체중감소에 긍정적인 효과를 나타내는 것으로 판단된다. 비만관리프로그램 연구가 주로 영양교육을 통해 식습관을 교정하여 비만관리를 하
거나 운동위주로 비만관리(Kang \& Kim, 2004)를 하는 것에 비 해 본 체중관리프로그램은 영양교육과 운동을 함께 병행하여 체 중감소효과를 상승시키고 체성분구성 중 체지방을 감소시키면서 제지방의 감소를 최대한 막고자 하는데 의의가 있다.

\section{3. 체력-근력, 유연성, 근지구력의 변화}

체중관리프로그램 참여 전 후의 체력변화는 Table 4 와 같다. 근력의 경우 $\mathrm{WM}-\mathrm{NE}$ 군은 $29.26 \pm 3.70 \mathrm{~kg}$ 에서 $31.35 \pm 3.14$ $\mathrm{kg}$ 으로, $\mathrm{WM}-\mathrm{E}$ 군은 $25.71 \pm 5.37 \mathrm{~kg}$ 에서 $28.17 \pm 4.47 \mathrm{~kg}$ 으 로 증가하였으며, 유연성은 $\mathrm{WM}-\mathrm{NE}$ 군은 $11.85 \pm 8.79 \mathrm{~cm}$ 에 서 $14.96 \pm 7.63 \mathrm{~cm}$ 로 $\mathrm{WM}-\mathrm{E}$ 군은 $6.93 \pm 4.80 \mathrm{~cm}$ 에서 12.11 $\pm 4.96 \mathrm{~cm}$ 로 유의적으로 증가하였으며 근지구력은 $\mathrm{WM}-\mathrm{NE}$ 군은 $10.76 \pm 5.14 \mathrm{reps} / \mathrm{min}$ 에서 $14.12 \pm 4.90 \mathrm{reps} / \mathrm{min}$ 으 로, $\mathrm{WM}-\mathrm{E}$ 군은 $9.87 \pm 6.57 \mathrm{reps} / \mathrm{min}$ 에서 $14.31 \pm 4.89 \mathrm{reps} /$ $\min$ 으로 유의적으로 증가하였다. 비만인에게 유연성의 감소는 운동수행능력의 감소를 초래하여 운동자체를 꺼려하는 운동습관 으로 변화될 우려가 있는데 본 연구 결과 유연성이 증가한 것은 관절의 운동범위를 증가시키고 근손상에 대한 위험성을 감소시 켜 운동수행 능력을 증진시키는 바람직한 변화이며 다른 연구결 과와도 일치한다(Swift et al., 2014). 운동은 고혈압을 가진 동 물모델과 사람에서 혈관을 이완시키며, 혈관내피기능이 향상되 어 동맥의 탄력성이 증가되어 심혈관계와 관련된 관상동맥경화 증, 제 2 형 당뇨병 및 이상지질혈증 등의 질환을 개선시키는 것으 로 알려져 있다(Kim \& Kim, 2010). 그러나 본 연구의 3개월 동 안의 운동은 단기적인 효과로 좀 더 장기간의 추적 연구가 필요 하다고 사료되며 운동프로그램 참여 이후의 추적조사와 연구대 상자 인원수가 적은 것은 제한 점이었다.

Table 4. Comparison of physical strength changes in the WM-NE and WM-E groups, consisting of middle-aged women with obesity

\begin{tabular}{llcccc}
\hline \multirow{3}{*}{ Muscular Strength (kg) } & & Before & After & $t$ & $p$ \\
& WM-NE & $29.26 \pm 3.70$ & $31.45 \pm 3.14$ & -3.616 & 0.003 \\
\multirow{3}{*}{ Flexibility (cm) } & WM-E & $25.71 \pm 5.37$ & $28.17 \pm 4.47$ & -3.312 & 0.005 \\
\multirow{3}{*}{ Muscular endurance (reps/min) } & WM-NE & $11.85 \pm 8.79$ & $14.96 \pm 7.63$ & -3.846 & 0.001 \\
& WM-E & $6.93 \pm 4.80$ & $12.11 \pm 4.96$ & -5.710 & 0.001 \\
& WM-NE & $10.76 \pm 5.14$ & $14.12 \pm 4.90$ & -6.348 & 0.001 \\
& WM-E & $9.87 \pm 6.57$ & $14.31 \pm 4.89$ & -4.919 & 0.001 \\
\hline
\end{tabular}

WM-NE, weight management program-nutrition education and exercise; WM-E, weight management program-exercise.

Data are represented as mean \pm standard deviation $(p<0.05)$.

Table 5. Comparison of calcium, zinc, and iron intake of the WM-NE and WM-E groups, consisting of middle-aged women with obesity

\begin{tabular}{llcccc}
\hline \multirow{2}{*}{ Calcium (mg) } & & Before & After & $t$ & $p$ \\
\multirow{3}{*}{ Zinc (mg) } & WM-NE & $427.86 \pm 122.75$ & $368.46 \pm 47.79$ & 2.367 & 0.031 \\
\multirow{2}{*}{ Iron (mg) } & WM-E & $395.82 \pm 108.83$ & $366.95 \pm 93.39$ & 0.933 & 0.065 \\
& WM-NE & $9.07 \pm 7.28$ & $5.84 \pm 0.99$ & 1.921 & 0.073 \\
& WM-E & $7.10 \pm 0.96$ & $6.51 \pm 1.35$ & 1.704 & 0.109 \\
\hline
\end{tabular}

WM-NE, weight management program-nutrition education and exercise; WM-E, weight management program-exercise. Data are represented as mean \pm standard deviation $(p<0.05)$. 


\section{4. 칼슘, 아연, 철 섭취 변화}

체중관리프로그램 참여 전 후의 칼슘, 아연, 철의 섭취는 Table 5에 제시하였다. 2015년 질병관리본부에서 실시한 국 민건강영양조사(Korea Centers for Disease Control and Prevention, 2017)에 따르면 우리나라 국민 칼슘 섭취 현황은 섭취 기준 대비 평균 섭취량이 남녀 모두 부족한 수준이라고 보 고하였는데 본 연구에서도 $\mathrm{WM}-\mathrm{NE}$ 군의 칼슘 섭취량은 427.86 $\pm 122.75 \mathrm{mg}$, 교육이 끝난 후에는 $368.46 \pm 47.79 \mathrm{mg}$ 으로 더 감소하였다. $\mathrm{WM}-\mathrm{E}$ 군은 $395.82 \pm 108.83 \mathrm{mg}$ 을 섭취하였으며 교육 후에는 $366.95 \pm 93.39 \mathrm{mg}$ 으로 감소하여 두 군 모두 같은 경향이었으나 유의성을 나타내지는 않았다. 이 같은 결과는 두 군 모두 음식의 섭취가 전반 적으로 줄어들면서 칼슘의 섭취량도 감소한 것으로 사료된다. 칼슘이 풍부한 식사는 체중, 체질량지 수, 체지방량, 복부지방량을 감소시키며 비만유병률을 낮춘다고 보고한바(Zemel et al., 2004), 칼슘섭취를 증가시키는 방안이 필요하다고 사료된다. 칼슘은 인체의 골격을 구성하는 가장 주 가 되는 영양소로 체내의 골량은 성장기 동안 증가하다가 약 25 세경에 최고에 이르며 남성과 여성 모두 40세가 넘으면 뼈의 질 량이 감소하기 시작한다(Papakonstantinou et al., 2003). 골 밀도에 영향을 주는 인자는 유전적 요인, 칼슘 섭취 부족, 인의 과잉 섭취, 동물성 단백질과 나트륨의 다량 섭취, 비타민 D 결핍 등의 식이 요인과 운동부족, 알코올, 흡연 등이 골밀도에 부정적 인 요인으로 보고되고 있다(Zhu et al., 2005). 호르몬의 변화 와 함께 골밀도 저하 및 골소실률이 높아지는 폐경기 여성의 경 우 골다공증 예방을 위한 적정 수준의 칼슘 섭취는 필수적이다 (Hur et al., 2018). 본 연구에서 체중관리 참여 전에도 칼슘섭 취량이 $\mathrm{WM}-\mathrm{NE}$ 군, $427 \mathrm{mg}, \mathrm{WM}-\mathrm{E}$ 군은 $395 \mathrm{mg}$ 으로 한국인 칼슘 권장 영양소 섭취기준인 30-49세 $700 \mathrm{mg}, 50-64$ 세 800 $\mathrm{mg}$ 에 비해 부족하게 섭취하고 있었으며, 체중관리프로그램 참
여 후에는 두 군 모두 $368 \mathrm{mg}, 366 \mathrm{mg}$ 정도로 더 낮아져 노년 기 뼈 건강을 위해 칼슘의 섭취를 증가시켜야 할 필요가 있다고 생각된다. 폐경 전과 후의 여성에 골밀도와 관련된 인자들을 알 아보기 위한 연구(Compston et al., 1992)에 의하면, 폐경 전 여성이 복부비만도가 높을수록 낮은 골밀도를 갖는다고 하였고 (Compston et al., 1992), 폐경 후 여성에서 신체조성과 골밀도 의 관계를 알아보는 연구에서는 비만이 폐경 후 여성의 골다공증 발생의 보호인자로 작용한다고 하였다(Van Loan et al., 1998). 한편 체중감소가 골밀도에 미치는 영향을 알아보기 위한 연구에 서는 체지방률 39-54\% 여성에게 체중감량을 실시한 결과 체중 감소와 함께 골밀도가 감소하였다고 보고하였다(Hamilton et al., 2013). 이를 종합해보면, 복부비만 여성은 낮은 골밀도의 경향을 보이고 다이어트를 위해 체중감소를 하면 골밀도가 더 낮 아진다는 것을 의미하기도 한다. 그러므로 체중을 감소할 때 따 르는 골밀도의 감소는 중년기 이후 여성들에게는 더욱 치명적 일 수 있기 때문에 골밀도를 증가시키기 위해 단백질, 칼슘, 비 타민 D, 비타민 C 등의 영양소를 충분히 섭취하고 뼈를 생성하 는 조골세포를 자극하는 운동을 꾸준히 해야 한다. 본 연구에 서 교육 후 체지방이 감소한 것은 바람직하나 칼슘 섭취 감소에 대해서는 좀 더 추적연구가 진행되어야 할 것이다. 아연 섭취량 은 $\mathrm{WM}-\mathrm{NE}$ 군은 교육 전 $9.07 \pm 7.28 \mathrm{mg}$ 에서 교육 후 $5.84 \pm$ $0.99 \mathrm{mg}, \mathrm{WM}-\mathrm{E}$ 군은 $7.10 \pm 0.96 \mathrm{mg}$ 에서 $6.51 \pm 1.35 \mathrm{mg}$ 으 로 감소하였으나 유의성은 보이지 않았으며, 2015년 한국인 영 양소 섭취기준 30-49세 여성 권장섭취량 $8.0 \mathrm{mg}$ 에 미치지 못 하게 섭취하였다. 비만인 사람들은 열량 과잉과 미량 영양소 섭 취 부족으로 인하여 영양불균형 상태가 나타나며 면역능력이 저 하된다고 한다(Luque-Díaz et al., 1982; No, 2012). 식이에 서 아연이 부족되게 섭취되는 것은 긍정적이지 못한 결과로 체중 감량 프로그램에서 에너지와 지방, 탄수화물은 감소하여도 미량

Table 6. Comparison of daily nutrient intake of the WM-NE and WM-E groups, consisting of middle-aged women with obesity

\begin{tabular}{|c|c|c|c|c|c|}
\hline & & Before & After & $t$ & $p$ \\
\hline \multirow{2}{*}{ Energy intake (kcal) } & WM-NE & $1,684.83 \pm 278.56$ & 1,388.39 \pm 133.17 & 2.552 & 0.021 \\
\hline & WM-E & $1,890.85 \pm 279.87$ & $1,482.48 \pm 149.10$ & 6.359 & 0.001 \\
\hline \multirow{2}{*}{ Carbohydrate (g) } & WM-NE & $291.36 \pm 52.05$ & $213.88 \pm 24.76$ & 2.567 & 0.021 \\
\hline & WM-E & $336.03 \pm 22.85$ & $215.07 \pm 21.95$ & 8.559 & 0.001 \\
\hline \multirow{2}{*}{ Carbohydrate (\%) } & WM-NE & $69.19 \pm 4.33$ & $65.62 \pm 17.14$ & 3.027 & 0.020 \\
\hline & WM-E & $71.08 \pm 5.14$ & $58.03 \pm 15.99$ & 2.460 & 0.030 \\
\hline \multirow{2}{*}{ Protein (g) } & WM-NE & $80.91 \pm 12.85$ & $73.45 \pm 6.42$ & 2.903 & 0.010 \\
\hline & WM-E & $68.29 \pm 9.52$ & $108.98 \pm 6.90$ & 3.129 & 0.007 \\
\hline \multirow{2}{*}{ Protein (\%) } & WM-NE & $19.20 \pm 2.22$ & $21.16 \pm 10.25$ & -0.793 & 0.439 \\
\hline & WM-E & $24.83 \pm 12.20$ & $29.40 \pm 13.21$ & -1.054 & 0.313 \\
\hline \multirow{2}{*}{ Fat (g) } & WM-NE & $21.07 \pm 8.28$ & $16.65 \pm 4.78$ & 1.171 & 0.259 \\
\hline & WM-E & $36.89 \pm 9.76$ & $19.23 \pm 6.63$ & 2.653 & 0.018 \\
\hline \multirow{2}{*}{ Fat (\%) } & WM-NE & $11.26 \pm 3.18$ & $10.79 \pm 7.00$ & -1.371 & 0.189 \\
\hline & WM-E & $17.25 \pm 9.21$ & $11.67 \pm 2.60$ & 1.946 & 0.075 \\
\hline
\end{tabular}

WM-NE, weight management program-nutrition education and exercise; WM-E, weight management program-exercise. Data are represented as mean \pm standard deviation $(p<0.05)$. 
영양소가 부족되지 않게 하는 것이 중요하다고 생각된다. 철분의 섭취량은 $\mathrm{WM}-\mathrm{NE}$ 군은 $11.28 \pm 2.91 \mathrm{mg}$ 에서 교육 후 $9.46 \pm$ $1.52 \mathrm{mg}, \mathrm{WM}-\mathrm{E}$ 군은 $11.67 \pm 2.04 \mathrm{mg}$ 에서 $9.81 \pm 1.73 \mathrm{mg}$ 으로 감소하여 유의적인 차이는 나타내지 않았으나, 2015년 한 국인 영양소 섭취기준 30-49세 여성 권장섭취량 $14.0 \mathrm{mg}$ 에 미 치지 못하였다. 이는 식사량이 감소하면서 전반적으로 영양소 섭 취가 감소한 것이 원인으로 사료된다. 철분은 호흡계 내에서의 산소 및 탄산가스 운반, 효소의 구성 성분, 면역, 감염 및 인지능 력 등에 관여하는 중요한 영양소이다(Dallman, 1987; Pollitt et al., 1986). 본 연구에서 철분 섭취함량이 낮은 이유는 철분 섭취의 상당량을 흡수율이 낮은 식물성 식품 위주로 섭취한 경향 도 하나의 요인으로 작용했을 것으로 사료된다.

\section{5. 열량 영양소 섭취에 미치는 영향}

체중관리프로그램이 식이섭취량의 변화에 미치는 영향을 분 석한 결과는 Table 6 및 Table 7에 제시하였다. WN-NE군 과 $\mathrm{WN}-\mathrm{E}$ 군 모두 에너지 섭취량이 감소하였다. 총 에너지 섭 취량은 $\mathrm{WN}-\mathrm{NE}$ 군 $1684.83 \pm 278.56 \mathrm{kcal} /$ 일에서 1388.39 $\pm 133.17 \mathrm{kcal} /$ 일로 감소하였으며, $\mathrm{WN}-\mathrm{E}$ 군은 $1890.85 \pm$ $279.87 \mathrm{kcal} /$ 일에서 $1482.48 \pm 149.10 \mathrm{kcal} /$ 일로 감소하였다. 이는 2015년 한국인 영양소 섭취기준에서 정하는 에너지 필요 추정량 30-49세 1,900 kcal, 50-64세 1,800 kcal에 비해 프 로그램 수행 전·후 모두 부족되게 섭취하였다. 본 연구의 이 같 은 결과는 비만 중년여성들이 프로그램 참여 전에도 체중감량을 위해 식사조절을 하였고, 프로그램 참여 후에는 식사일지를 쓰 면서 음식조절을 하였기 때문이며, 특히 $\mathrm{WM}-\mathrm{NE}$ 군은 영양교 육도 일조한 것으로 사료된다. 탄수화물의 섭취량은 $\mathrm{WN}-\mathrm{NE}$ 군은 $291.36 \pm 52.05 \mathrm{~g}$ 에서 $213.88 \pm 24.76 \mathrm{~g}$ 으로 감소하였 으며, $\mathrm{WN}-\mathrm{E}$ 군은 $336.03 \pm 22.85 \mathrm{~g}$ 에서 $215.07 \pm 21.95 \mathrm{~g}$ 으 로 감소하였다. 총 에너지에서 차지하는 탄수화물의 비율은 체 중관리교육프로그램 참여 전에는 $\mathrm{WN}-\mathrm{NE}$ 군은 $69.19 \pm 4.33 \%$, $\mathrm{WN}-\mathrm{E}$ 군은 $71.08 \pm 5.14 \%$ 였으나, 체중관리 교육프로그램이 끝
난 후에는 $65.62 \pm 17.14 \%, 58.03 \pm 15.99 \%$ 로 감소하여 2015 년 한국인 영양소 섭취기준에서 제시한 19 세 이상 에너지 적정 비율인 55-65\% 범위에 있었다. 탄수화물의 과잉 섭취는 체중 증가뿐 아니라 체내에서 중성지방으로 전환되어 이상지질혈증 의 한 원인이 되므로 탄수화물의 섭취가 감소한 것은 바람직한 경향으로 사료된다. 영양소 섭취비율은 달라도 탄수화물, 지방 의 과잉섭취는 비만을 유발하며 특히 여성은 과일이나 채소로부 터 섭취한 탄수화물은 허리둘레와 음의 연관성을 보이나 곡류에 서 섭취한 탄수화물은 허리둘레와 양의 연관성을 보인다고 하여 탄수화물과 지방 조절이 비만관리에서 중요하다고 강조하였다

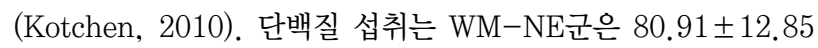
$\mathrm{g}$ 에서 $73.45 \pm 6.42 \mathrm{~g}$ 으로 감소하였으며, WM-E군은 68.29 $\pm 9.52 \mathrm{~g}$ 에서 $108.98 \pm 6.90 \mathrm{~g}$ 으로 증가하였다. 단백질비율은 $\mathrm{WM}-\mathrm{NE}$ 군은 $19.20 \pm 2.22 \%$ 에서 $21.16 \pm 10.25 \%$ 로 증가하였 으며 $\mathrm{WM}-\mathrm{E}$ 군은 $24.83 \pm 12.20 \%$ 에서 $29.40 \pm 13.21 \%$ 로 증가 하였으나 유의적인 차이는 보이지 않았다. 2015년 한국인 영양 소 섭취기준에서는 적정 단백질 섭취비율을 19 세 이상 성인의 경우 7-20\%로 제시하였는데 $\mathrm{WM}-\mathrm{NE}$ 군은 교육 후에도 비슷 한 비율이나 운동만 한 군은 $29 \%$ 로 한국인 영양섭취기준에 비해 많이 섭취하였다. 단백질은 많이 섭취해도 저장이 되지 않고 산 화시키거나 다른 방법으로 제거하여야 하므로 산화증가는 열 발 생을 증가시켜 체중감량에 일조한 것으로 생각된다(Midgley et al., 1996). 단백질 함량이 높은 식사는 체지방을 감소시켜 체중 을 저하시킬 뿐 아니라 체중 감소 후 이를 유지하는데도 효과적 이라고 하며 복부비만을 감소시키는 효과가 있다고 한다(Blum et al., 1989). 그러나 과잉의 단백질은 골격으로부터 칼슘을 용 출시켜 골다공증의 요인으로 작용할 수 있으므로 중년 여성에게 있어 단백질과 칼슘의 비율은 중요하다고 사료된다. 지방섭취량 은 $\mathrm{WM}-\mathrm{NE}$ 군은 $21.07 \pm 8.28 \mathrm{~g}$ 에서 $16.65 \pm 4.78 \mathrm{~g}$ 으로 감소 하였으며, $\mathrm{WM}-\mathrm{E}$ 군은 $36.899 .76 \mathrm{~g}$ 에서 $19.23 \pm 6.63 \mathrm{~g}$ 으로 감소하였다. 지방이 총 에너지에서 차지하는 비율은 $\mathrm{WM}-\mathrm{NE}$ 군 은 $11.26 \pm 3.18 \%$ 에서 $10.79 \pm 7.00 \%$ 로 $\mathrm{WM}-\mathrm{E}$ 군은 $17.25 \pm$

Table 7. Comparison of dietary cholesterol, SFA, MUFA, and PUFA intake in the WM-NE and WM-E groups, consisting of middle-aged women with obesity

\begin{tabular}{|c|c|c|c|c|c|}
\hline & & Before & After & $t$ & $p$ \\
\hline \multirow{2}{*}{ Total fatty acid (g) } & WM-NE & $16.02 \pm 5.51$ & $14.35 \pm 2.77$ & 1.331 & 0.202 \\
\hline & WM-E & $18.06 \pm 7.05$ & $15.32 \pm 3.32$ & 1.713 & 0.107 \\
\hline \multirow{2}{*}{ Saturated fatty acid (g) } & WM-NE & $4.94 \pm 2.27$ & $4.69 \pm 1.24$ & 0.482 & 0.637 \\
\hline & WM-E & $5.79 \pm 2.66$ & $4.94 \pm 1.36$ & 1.473 & 0.161 \\
\hline \multirow{2}{*}{ Monounsaturated fatty acid (g) } & WM-NE & $5.81 \pm 2.42$ & $5.34 \pm 1.02$ & 0.833 & 0.417 \\
\hline & WM-E & $6.72 \pm 2.92$ & $5.72 \pm 1.31$ & 1.503 & 0.154 \\
\hline \multirow{2}{*}{ Polyunsaturated fatty acid (g) } & WM-NE & $5.15 \pm 1.61$ & $4.31 \pm 0.97$ & 2.057 & 0.056 \\
\hline & WM-E & $5.53 \pm 2.29$ & $4.64 \pm 0.99$ & 1.685 & 0.113 \\
\hline
\end{tabular}

SFA, saturated fatty acid; MUFA, monounsaturated fatty acid; PUFA, polyunsaturated fatty acid; WM-NE, weight management program-nutrition education and exercise; WM-E, weight management program-exercise.

Data are represented as mean \pm standard deviation $(p<0.05)$. 
$9.21 \%$ 에서 $11.67 \pm 2.60 \%$ 로 감소하여 2015년 한국인 영양소섭 취기준에서 정하는 15-30\%보다 부족하게 섭취하였다. 지방은 동물성 식품에 많은 포화지방산, 식물성 식품에 많은 불포화지방 산의 형태로 존재하며 이들 식품의 섭취 비율 또한 중요하다. 이 들 영양소 섭취결과는 Table 7에 제시하였다. 포화지방산 섭취 는 WM-NE군은 4.94 $\pm 2.27 \mathrm{~g}$ 에서 $4.69 \pm 1.24 \mathrm{~g}$ 로 WM-E군 은 $5.79 \pm 2.66 \mathrm{~g}$ 에서 $4.94 \pm 1.36 \mathrm{~g}$ 로 감소하였으며, 단일불포 화지방산은 $\mathrm{WM}-\mathrm{NE}$ 군은 $5.81 \pm 2.42 \mathrm{~g}$ 에서 $5.34 \pm 1.02 \mathrm{~g}$ 로 $\mathrm{WM}-\mathrm{E}$ 군은 $6.72 \pm 2.92 \mathrm{~g}$ 에서 $5.72 \pm 1.31 \mathrm{~g}$ 로 감소하였으며, 다가불포화지방산은 $\mathrm{WM}-\mathrm{NE}$ 군은 $5.15 \pm 1.61 \mathrm{~g}$ 에서 $4.31 \pm$ $0.97 \mathrm{~g}$ 로, $\mathrm{WM}-\mathrm{E}$ 군은 $5.53 \pm 2.29 \mathrm{~g}$ 에서 $4.64 \pm 0.99 \mathrm{~g}$ 로 감 소하여 포화지방산, 단일불포화지방산, 다가불포화지방산의 섭 취가 감소하였으나 유의적인 차이는 보이지 않았다. 이 같은 결 과는 본 연구에서 체중관리프로그램 참여 전에도 지방의 섭취는 높지 않았으며 프로그램참여 후에는 체중조절을 위해 전반적으 로 식사량이 감소하여 지방섭취도 감소한 것으로 보이며 우리 식 사가 지방이 많은 식품보다는 곡류위주의 식품으로 구성되어 있 는 것도 일조한 것으로 사료된다. 이상의 결과 중년기 여성의 건 강은 향후 노년기 건강에 매우 중요하므로 체중을 정상으로 유지 하면서 지속적인 영양관리가 필요하다고 판단된다. 특히 중·노년 기 여성의 뼈 건강에 중요한 칼슘 섭취 부족을 개선시키기 위한 다각적인 방안이 제시되어야 한다고 생각한다.

\section{Conclusion}

체중관리프로그램은 체중, 체지방, 체지방율, 허리둘레, 복부 비만율을 감소시키고 근력, 유연성, 근지구력은 증가시켜 중년비 만여성의 비만개선과 체력 증진에는 긍정적이었다. 또한 전체 에 너지 섭취에서 탄수화물과 지방의 섭취 비율은 감소하고 단백질 비율의 섭취는 증가하여 체중관리프로그램이 비만개선에 효과적 임을 확인하였다. 그러나 칼슘, 아연, 철분 섭취량은 감소하였으 며, 특히 칼슘 섭취가 부족하였다. 중·노년기 이후의 칼슘 섭취 부족은 근·골격계 질환 등을 발현시킬 수 있으므로 비만인 중년 여성을 대상으로 한 체중관리프로그램은 칼슘의 섭취가 부족하 지 않게 구성되어야 한다고 제안하는 바이다.

\section{References}

Blum M, Averbuch M, Wolman Y, Aviram A. Protein intake and kidney function in humans: it's effect on 'normal aging'. Archives of Internal Medicine, 149: 211-212, 1989.
Chen MD, Lin PY, Lin WH, Cheng V. Zinc in hair and serum of obese individuals in Taiwan. The American Journal of Clinical Nutrition, 48: 1307-1309, 1988.

Compston JE, Bhambhani M, Laskey MA, Murphy S, Khaw KT. Body composition and bone mass in postmenopausal women. Clinical Endocrinology, 37: 426431, 1992.

Dallman PR. Iron deficiency and the immune response. The American Journal Clinical Nutrition, 46: 329-334, 1987.

Friedman JM. Obesity: causes and control of excess body fat. Nature, 459: 340-342, 2009.

Hamilton KC, Fisher G, Roy JL, Gower BA, Hunter GR. The effects of weight loss on relative bone mineral density in premenopausal women. Obesity, 21: 441-448, 2013.

Hur JE, Park JH, Kim Y, Kim H, Lee M, Kim JH, Ko KS. Analysis of consumption status of calcium with related factors in a Korean population: based on data from the 2013 2015 Korean national health and nutritional examination survey (KNHANES). Journal of Korean Society of Food Science and Nutrition, 47: 328-336, 2018.

Ilich JZ, Kelly OJ, Inglis JE, Panton LB, Duque G, Ormsbee MJ. Interrelationship among muscle, fat, and bone: connecting the dots on cellular, hormonal, and whole body levels. Ageing Research Reviews, 15: 51-60, 2014.

Kang JS, Kim HS. A study on the evaluation of a nutritional education program for the middle aged obese women. The Korean Journal of Food and Nutrition, 17: 356-367, 2004.

Karvonen-Gutierrez C, Kim C. Association of mid-life changes in body size, body composition and obesity status with the menopausal transition. Healthcare, 4: 42, 2016.

Kim NS, Kim SH. Effects of a 10 week aerobic exercise on body composition, blood lipid, oxidative stress and hsCRP of adult obese women. The Korean Society of Sports Science, 26: 1007-1017, 2017.

Kim HK, Kim MJ. Effects of weight control program on dietary habits and blood composition in obese middle aged women. Journal of Nutrition and Health, 43: 273284, 2010.

Kim SA, Sim EK. Effects of weight loss knowledge, attitude, and motivation on dietary habits among college students in their twenties. Asian Journal of Beauty and Cosmetology, 16: 20-31, 2018. 
Kim SH. Effects of a 12-week walking exercise on body composition, metabolic-related variables and stressrelated variables in middle-age obese women. The Korean Society of Sports Science, 26: 867-877, 2017.

Kotchen TA. Obesity-related hypertension: epidemiology, pathophysiology, and clinical management. American Journal of Hypertension, 23: 1170-1178, 2010.

Korea Centers for Disease Control and Prevention. 2016 Health behavior and chronic disease statistics. Korea Centers for Disease Control and Prevention, Cheongju, 2017.

Lee KS, Lee JH. Effect of the dietary approaches to stop hypertension diet with aerobic exercise on body composition and blood lipid profiles in obese individuals. Journal of Exercise Nutrition \& Biochemistry, 14: 17-21, 2010.

Lim U, Ernst T, Buchthal SD, Latch M, Albright CL, Wilkens LR, Kolonel LN, Murphy SP, Chang L, Novotny R, Le Marchand L. Asian women have greater abdominal and visceral adiposity than Caucasian women with similar body mass index. Nutrition \& Diabetes, 1: e6, 2011.

Lin WH, Chen MD, Lin PY. Investigation of the profile of selected trace metals in genetically obese (ob/ob) and lean (+/?) mice. Journal of the Formosan Medicine Association, 91: S27-S33, 1992.

Locniskar M, Nauss KM, Newberne PM. The effect of quality and quantity of dietary fat on the immune system. Journal of Nutrition, 113: 951-961, 1983.

Luque-Díaz MJ, Dean-Guelbenzu M, Culebras-Poza JM. Changes in the metabolism of iron, copper and zinc in obesity. Revista Española de Fisiología, 38: S155-S158, 1982.

Matthews CE, Sui X, LaMonte MJ, Adams SA, Hebért JR, Blair $\mathrm{SN}$. Metabolic syndrome and risk of death from cancers of the digestive system. Metabolism, 59: 1231-1239, 2010.

Midgley JP, Matthew AG, Greenwood CM, Logan AG. Effect of reduced dietary sodium on blood pressure: a meta- analysis of randomized controlled trials. The Journal of the American Medical Association, 275: 1590-1597, 1996.

No JK. The effective diet for obesity through preventing silent inflammation. Asian Journal of Beauty and Cosmetology, 10: 1-6, 2012.

Papakonstantinou E, Flatt WP, Huth PJ, Harris RB. High dietary calcium reduces body fat content, digestibility of fat, and serum vitamin D in rats. Obesity Research, 11: 387-394, 2003.

Peacock M. Calcium metabolism in health and disease. Clinical Journal of the American Society of Nephrology, 5: S23-S30, 2010.

Pollitt E, Saco-Politt C, Leibel RL, Viteri FE. Iron deficiency and behavioral development in infants and preschool children. The American Journal of Clinical Nutrition, 43: 555-565, 1986.

Rachner TD, Khosla S, Hofbauer LC. Osteoporosis: now and the future. Lancet, 377: 1276-1287, 2011.

Swift DL, Johannsen NM, Lavie CJ, Earnest CP, Church TS. The role of exercise and physical activity in weight loss and maintenance. Progress in Cardiovascular Diseases, 56: 441-447, 2014.

Van Loan MD, Johnson HL, Barbieri TF. Effect of weight loss on bone mineral content and bone mineral density in obese women. The American Journal of Clinical Nutrition, 67: 734-738, 1998.

Zemel MB, Thompson W, Milstead A, Morris K, Campbell $P$. Calcium and dairy acceleration of weight and fat loss during energy restriction in obese adults. Obesity Research, 12: 582-590, 2004.

Zhu K, Du X, Cowell CT, Greenfield H, Blades B, Dobbins TA, Zhang Q, Fraser DR. Effects of school milk intervention on cortical bone accretion and indicators relevant to bone metabolism in Chinese girls aged 10-12 y in Beijing. The American Journal of Clinical Nutrition, 81: 1168-1175, 2005. 


\section{국문초록}

\section{체중관리 프로그램이 중년비만여성의 체성분과 칼슘, 아연, 철 섭취에 미치는 영향}

한정순 ${ }^{1}$, 김유경 ${ }^{2 *}$

${ }^{1}$ 고려대학교 사범대학 가정교육과 생활과학연구소, 서울, 한국

${ }^{2}$ 고려대학교 사범대학 가정교육과, 서울, 한국

목적: 본 연구는 중년비만여성들을 대상으로 한 체중관리프로그램이 체성분, 체력관련 인자들 및 칼슘, 아연, 철과 다른 영양소 섭 취 등에 미치는 영향을 관찰하기 위해 수행되었다. 방법: 중년비만여성을 WM-NE (weight management-nutrition and exercise) 군과 WM-E (weight management-exercise)군으로 나누어 3개월간 신체계측과 체력을 측정하고 식이섭취조사를 하였다. 결과: $\mathrm{WM}-\mathrm{E}$ 군과 $\mathrm{WM}-\mathrm{E}$ 군 모두 체중, $\mathrm{BM}$, 체지방, 허리둘레, 허리엉덩이 둘레 비율이 유의하게 감소하였다. WM-E군과 $\mathrm{WM}-\mathrm{E}$ 군 모두 유연성, 근지구력이 유의하게 증가하였다. $\mathrm{WM}-\mathrm{E}$ 군과 $\mathrm{WM}-\mathrm{E}$ 군의 칼슘, 아연, 철의 섭취량은 체중관리 프로그램 참여 후에 감소하였다. 결론: 이상의 결과 체중관리프로그램은 체지방과 허리둘레 등을 감소시키고 체력은 증가시켜 중년비만여성의 비만개 선에는 긍정적이었다. 그러나 칼슘, 아연, 철분 섭취량은 감소하였으며, 특히 칼슘섭취는 부족하여 이를 질적양적으로 높이기 위한 다양한 체중관리프로그램이 필요하다고 사료된다.

핵심어: 체중관리 프로그램, 칼슘, 아연, 철, 중년비만여성

\section{참고문헌}

강진순, 김희숙. 중년기 비만여성에 대한 영양교육 프로그램의 효과 평가에 관한 연구. 한국식품영양학회지, $17: 356-$ 367, 2004.

김남수, 김승환. 10 주간의 유산소운동이 비만 성인여성의 신체구성, 혈중지질, 산화스트레스 및 $\mathrm{hs}-\mathrm{CRP}$ 에 미치는 영향.

한국체육과학학회지, 26: 1007-1017, 2017.

김솔아, 심은경. 20 대 남녀 대학생의 다이어트 지식, 태도 및 동기가 식습관에 미치는 영향. 아시안뷰티화장품학술지, 16:

20-31, 2018.

김승환. 12 주간의 걷기 운동이 비만 중년 여성의 신체구성, 대사 관련 변인 및 스트레스 관련 변인에 미치는 영향. 한국체 육학회지, 26: 867-877, 2017.

김혜경, 김미정. 체중조절 프로그램이 중년기 비만여성의 식습관 및 혈액성분에 미치는 영향. Journal of Nutrition and

Health, 43: 273-284, 2010.

노재경. 미세염증제어를 통한 비만예방 식사요법. 아시안뷰티화장품학술지, 10: 1-6, 2012.

이경선, 이주형. DASH다이어트와 유산소운동이 비만민의 신체조성과 혈액변인에 미치는 영향. Journal of Exercise Nutrition \& Biochemistry, 14: 17-21, 2010.

질병관리본부. 2016 건강행태 및 만성질환통계: 국민건강영양조사 제 7 기 1차년도(2016) 및 제 12 차(2016) 청소년건강 행태온라인조사. 질병관리본부, 청주, 2017.

허자은, 박재희, 김유리, 김혜경, 이민수, 김정현, 고광석. 한국인 칼슘 섭취 실태와 관련 요인: 제6기(2013 2015) 국민

건강영양조사 자료를 이용하여. 한국식품영양과학회지, 47: 328-336, 2018. 


\section{中文摘要}

\section{体重管理方案对中年肥胖女性身体成分，钻，锌，铁摄入量的影响}

韓正順 ${ }^{1}$, 金有京 ${ }^{*}$

${ }^{1}$ 高丽大学师范大学家政教育科生活科学研究所, 首尔, 韩国

2 高丽大学师范大学家政教育科, 首尔, 韩国

目的: 观察体重管理计划对中年肥胖妇女的身体成分, 体力活动以及钙, 锌, 铁和其他营养素摄入的影响。方 法: 将肥胖的中年女性分为以下两组：体重管理加营养教育和运动（WM-NE），体重管理和运动（WM-E）。然 后, 我们观察他们的人体测量参数, 身体活动和饮食摄入 3 个月。结果: 两组均显示平均体重, BMI, 体脂, 体 脂肪量, 腰围和腰慰比显着下降, 并且在参加体重管理计划后, 表现出耐力和灵活性的显着增加。参加体重管 理计划后, 两组的钙, 锌和铁摄入量均有所下降。结论: 因此, 体重管理计划减少了身体脂肪和腰围, 增加了身 体健康。这是中年肥胖患者改善肥胖的积极步骤。但是, 钙, 锌和铁的摄入量减少了; 特别是钙摄入量不足。 因此，我们希望研究体重管理计划，以改善中年肥胖妇女的骨骼健康。

关键词: 体重管理计划, 钙, 锌, 铁, 中年肥胖妇女 